\title{
Performance Measurement using the Integrated Performance Measurement System Approach
}

\author{
Nurul Aziza ${ }^{1^{*}}$, Patdono Suwignyo ${ }^{2}$, Ahmad Makki ${ }^{3}$ \\ ${ }^{1}$ Industrial Engineering Department, Universitas Maarif Hasyim Latif, Indonesia \\ Jalan Ngelom Megare, Taman Sidoarjo, Jawa Timur, Indonesia \\ ${ }^{2}$ Industrial Engineering Department, Insitut Teknologi Sepuluh Nopember Surabaya, Indonesia \\ Jl. Raya ITS, Keputih, Sukolilo, Surabaya, Jawa Timur 60111, Indonesia \\ ${ }^{3}$ Maarif Education and Social Foundations, Indonesia \\ Jalan Raya Ngelom, Taman, Sidoarjo, Indonesia \\ *Corresponding author: nurul_aziza@dosen.umaha.ac.id
}

\section{ARTICLE INFO}

Article history

Received October 11, 2018

Revised February 4, 2019

Accepted February 20, 2019

Available Online February 28, 2019

Keywords

Performance

School

IPMS

KPI

\begin{abstract}
As a non-profit organization in education, Senior High School has the responsibility to achieve educational goals. The school is required to have accountability to the public. Performance measurement is needed to determine organizational performance. Performance measurement can also find out the company's success in vision and mission. This study aims to measure performance in schools use an integrated performance measurement system (IPMS). This method becomes the starting point for setting goals and identifying Key Performance Indicators (KPI). The results of IPMS produced eight objectives and 33 KPIs. Objectives performance includes human resources, curriculum, finance, administration, teaching and learning activities, evaluation processes, work programs, and graduation. The results showed that $8 \mathrm{KPIs}$ were red, $4 \mathrm{KPIs}$ were yellow, and $11 \mathrm{KPIs}$ were green. This performance measurement model can also be used in other organizations. This performance measurement model helps assess organizational performance.
\end{abstract}

This is an open-access article under the CC-BY-SA license.

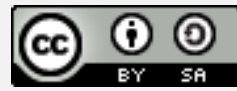

\section{Introduction}

The National Education System explains that national education functions to develop the ability of the nation. Moreover, the National Education System creates a noble character and national civilization to educate the nation's life. These are all listed in Law number 20 of 2003. The objectives are to develop the potential of students to become human beings who are faithful and devoted to the Almighty God. Furthermore, students have a noble, healthy, knowledgeable, capable, creative, independent character and become a democratic and responsible citizen. As one of the formal education institutions, the School carries out an education mission at the middle level. Furthermore, it is responsible for achieving institutional education goals. One of them is High School. As a non-profit organization, schools are required to be independent in 
seeking funds. It must have accountability to the community. Therefore, the School's performance needs to be controlled by the community. At present, school performance measurement is only in the form of the semester and annual activity reports. The activity was reported to the foundation and guardians of students. Through these semester and annual reports, overall organizational performance is challenging to measure by stakeholders.

In the performance organization, there are four essential aspects of organizational activity [1]. Academics recognize the importance of performance measurement. Furthermore, practitioners from various disciplines also recognize the importance of performance measurement [2]. Several studies have been conducted with performance measurement. Bititci, et al. [3] proposed the quantitative work measurement system model at school. The model is used to determine the choice of alternative strategies from performance evaluation. Bititci, et al. [4] developed an integrated model of performance measurement. The proposed model is a performance framework in an integrated work measurement system. Syairuddin, et al. [5] conducted performance measurements in universities using Integrated Performance Measurement Systems (IPMS).

In general, aspects of measuring performance are financial aspects. It encourages organizations to achieve profits in the short term. In addition to it, organizations need to consider other aspects of improving performance. Hence, companies need to have a performance measurement system that can present all organizational activities. Susetyo [6] used IPMS for the performance measurement of metal casting companies. He used an IPMS to identify KPIs from a stakeholder perspective. Widiyawati, et al. [7] proposed integrating performance prism with AHP to assess company organization. Maulidia, et al. [8] used IPMS to measure cooperative performance. Mas'idah, et al. [9] measured the value of company performance by combining AHP and Objective matrix (OMAX) methods. Rachman and Satoto [10] proposed measuring the performance of universities by combining IPMS, Analytic Hierarchy Process (AHP), Objective Matrix (OMAX), and Traffic Light System. Kurniyati, et al. [11] measured company performance by combining IPMS and AHP for weighting KPI. Susetyo and Sabakula [12] combined the IPMS method and the Balanced Scorecard to assess the performance of profit-oriented companies. They applied performance measurement to study programs in higher education. The study used the IPMS method, weighting KPI with AHP, and Objective Matrix (OMAX). Kurniawan, et al. [13] measured performance measurements in hospitals to provide a better waste treatment system. This measurement used the AHP (Analytical Hierarchy Process) and OMAX (Objective Matrix) methods. The method is used to design environmental performance systems in hospitals with medical and nonmedical care. Papilo [14] used the IPMS method to measure the performance of college faculties. He uses the integration of IPMS and SMART methods.

In previous studies, IPMS performance measurement methods were more widely applied to profit-oriented companies. Based on the literature review, no literature addresses performance measurement by combining IPMS, AHP, Objective Matrix (OMAX), and Traffic Light Scoring systems in high schools. Performance measurement is essential to do as a form of accountability to the community. Performance measurement is essential for educational organizations in high schools. This study aims to design a performance measurement model for schools from several KPIs. The design of this performance measurement is by combining IPMS, AHP, Objective Matrix (OMAX), and Traffic Light Scoring system. Interaction is done to facilitate and accelerate the identification of performance values based on color. This research is expected to be used as a raw model for the same schools. 


\section{Methods}

The stages of designing a system for measuring school performance was done by (1) identifying stakeholder requirements; (2) conduct external monitoring; (3) determine objectives (goals); (4) perform performance measurements called KPI (Key Performance Indicators), (5) validate KPIs; (6) calculating KPIs weight with the help of expert choice software; (7) measurement with OMAX (Objective matrix).

The initial stage in the IPMS method was the identification of stakeholder's requirements obtained by the interview method. The second stage was determining the objective and Key Performance Indicator (KPI). Distribution of questionnaires distributed to stakeholders as a form of validation. The weighting of KPI used the Analytical Hierarchy Process (AHP) method. The quantitative scale used is the range 1 to 9. This scale was used to assess the comparison of the importance of an element to other elements. The level of importance of the elements was done with a focus on group discussion. It obtained the level of importance of each aspect of stakeholder goals and KPI. The acquisition of this objective group was based on the Focus Group Discussion (FGD) with school management and foundations. The FGD was conducted by giving questionnaires and weighting for each objective with the pairwise comparison method. The organizational level is compiled based on the IPMS model. The level of the organization was divided into four levels (

Fig. 1). Fig. 2 illustrates the approach to the school organization system.

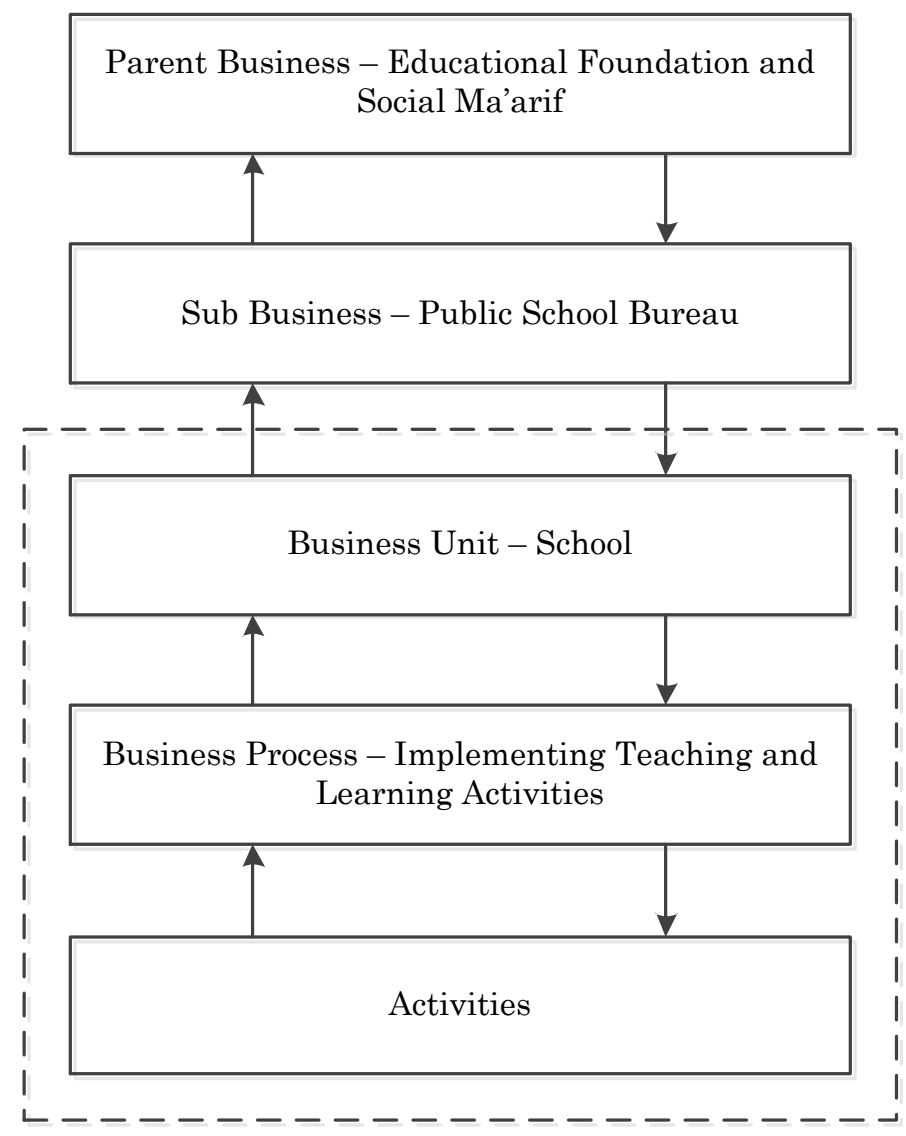

Fig. 1. School Organization Level 


\subsection{Identification of Stakeholder Requirement}

The starting point in the IPMS model was identifying the needs of parties with interest in the organization. However, it was also necessary to structure an integrated performance measurement model from the organization. Fig. 3 describes the design structure of the integrated performance measurement model of the organization. Table 1 shows Stakeholder's requirements (SR).

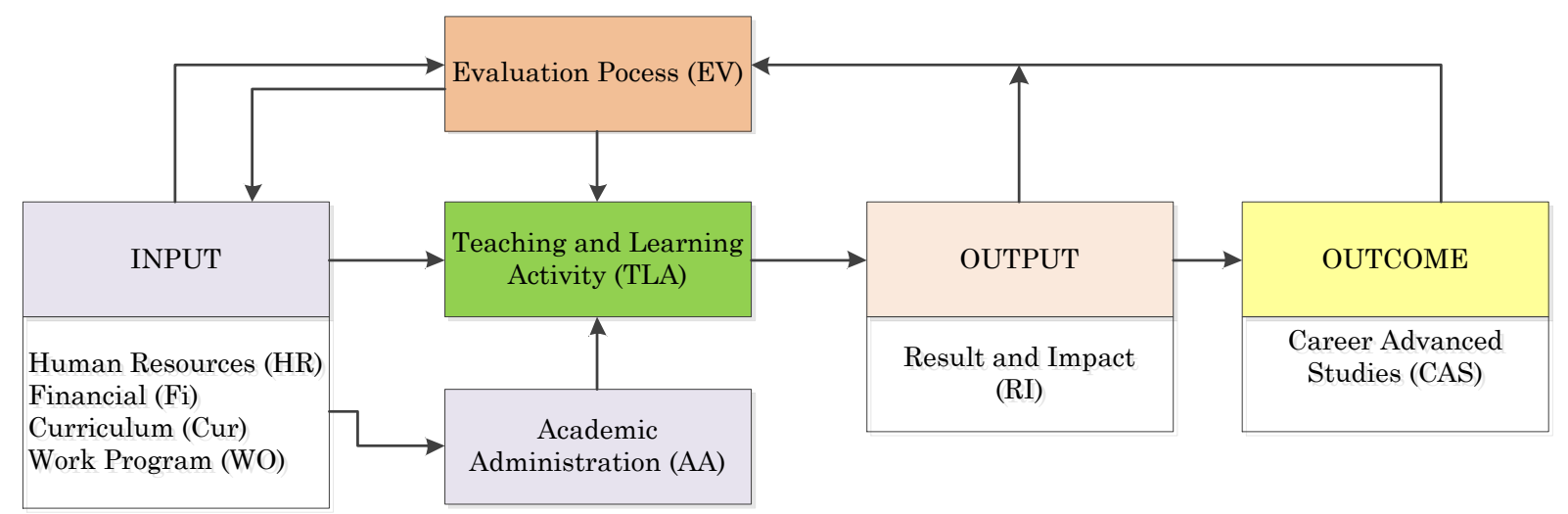

Fig. 2. School Organization System Approach

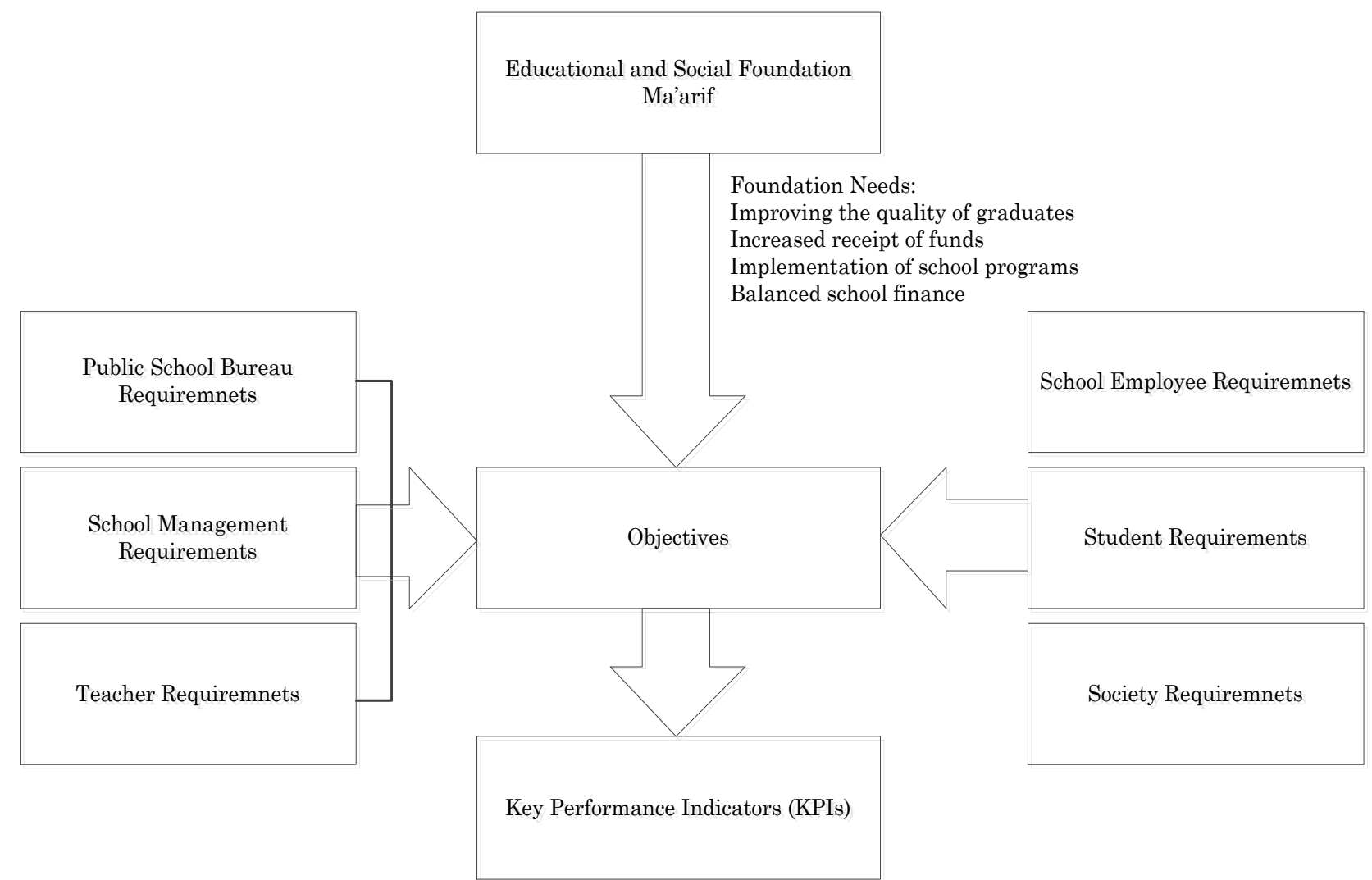

Fig. 3. The Design Structure of An Integrated Performance Measurement Model 
Table 1. The result of Stakeholder Requirements (SR)

No. Stakeholder Requirement

1. Ethics, morals, and loyalty of academic staff are high

2. Effectiveness of Teaching and Learning Activities (TLA)

3. Accountability to the public

4. Improving the quality of graduates who can speak English well

5. Realization of the school program

6. Development of the quality of academic staff resources

7. School finance is going well

8. Increase student interest in reading

9. Managerial tasks go well

10. graduates can compete with graduates from other schools to enter College

11. Increased welfare and reward

12. The readiness of TLA tools

13. Community trust in the school

14. Empowerment of school employees

15. The TLA implementation is following Unity of Lesson (UOL)

\subsection{External Monitoring}

The external monitoring was carried out by looking at the School Work Program. Monitoring was also based on the school curriculum development and development program and semester and annual school reports.

\subsection{Determine objectives and KPIs (Key Performance Indicators)}

Determination of objectives was obtained using an FGD by the performance design team and school administrators. Table 2 describes the results of the performance of the objective.

\subsection{Scoring Systems Objective Matrix (OMAX)}

The scoring system aims to determine the achievement of performance from the organization in a certain period. The calculation used Microsoft Excel software with the principle of interpolation. The results of the scoring system were used to create a traffic light system. The aim was to find out the score of the KPI. Three colors were used for indicators, such as:

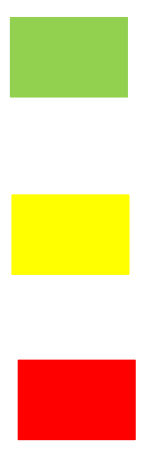

Green with a score threshold of 8.1-10

It means that the achievement of a KPI has reached the target set by management

Yellow with a score threshold 6,1-8

It means that the achievement of KPI has not been achieved even though the value is almost close to the target. Therefore management needs to be careful in addressing the yellow KPI

Red with a score threshold $\leq 6$

It means that achievement is far from the target set, there needs to be a follow-up improvement and design improvement efforts for achieving the target in the future. 
Table 2. Results of stakeholder requirements, objectives, and KPIs

\begin{tabular}{|c|c|c|}
\hline SR. & Objectives & KPIs Code and explanation \\
\hline \multirow[t]{2}{*}{1} & $\begin{array}{l}\text { 1. Increase the work ethic and morale of academic } \\
\text { staff }\end{array}$ & $\begin{array}{l}\text { 1. The average percentage of academic staff } \\
\text { attendance }\end{array}$ \\
\hline & $\begin{array}{l}\text { 2. Increase the loyalty of academic staff by } \\
\text { increasing the total number of permanent school } \\
\text { teachers }\end{array}$ & $\begin{array}{l}\text { 2. The ratio of permanent teachers to non- } \\
\text { permanent teachers }\end{array}$ \\
\hline \multirow[t]{2}{*}{2} & 3. Increase the effectiveness of TLA & 3. Percentage of total Free Time \\
\hline & & 4. Percentage of Student attendance \\
\hline \multirow[t]{2}{*}{3} & 4. Completing financial statements on time & $\begin{array}{l}\text { 5. Percentage of time for timely reporting of } \\
\text { financial statements }\end{array}$ \\
\hline & $\begin{array}{l}\text { 5. Complete the accountability regarding the } \\
\text { expenditure and receipt of funds }\end{array}$ & 6. The ratio of expenditure to revenue \\
\hline \multirow[t]{3}{*}{4} & $\begin{array}{l}\text { 6. Increase the acquisition of final grades for the } \\
\text { National Exam (NE) study field }\end{array}$ & 7. Average national exam score \\
\hline & & $\begin{array}{l}\text { 8. Achievement of the highest score target of } \\
\text { NE in the district. }\end{array}$ \\
\hline & 7. Improve student competence in English & 9. The average value of English subjects \\
\hline \multirow[t]{2}{*}{5} & $\begin{array}{l}\text { 8. Hold meetings aimed at socializing the school } \\
\text { program }\end{array}$ & 10. Meeting ratios on schedule \\
\hline & & $\begin{array}{l}\text { 11. The ratio of attendance of meeting } \\
\text { participants }\end{array}$ \\
\hline \multirow[t]{3}{*}{6} & 9. Hold training and supervision of school staff & $\begin{array}{l}\text { 12. The ratio of academic staff who attend } \\
\text { training }\end{array}$ \\
\hline & 10. Increasing the acquisition of supervision values & $\begin{array}{l}\text { 13. The average value of supervision of study } \\
\text { class teacher visits }\end{array}$ \\
\hline & $\begin{array}{l}\text { 11. Reducing the total academic staff with fewer } \\
\text { achievement values }\end{array}$ & $\begin{array}{l}\text { 14. Percentage of total academic staff with } \\
\text { achievement scores below } 6\end{array}$ \\
\hline \multirow[t]{3}{*}{7} & 12. Increase the target of receiving funds & $\begin{array}{l}\text { 15. Percentage of achievement of the target } \\
\text { acceptance (Tuition) }\end{array}$ \\
\hline & & 16. Percentage of receipt of alms funds \\
\hline & & 17. Percentage of arrears \\
\hline \multirow[t]{2}{*}{8} & $\begin{array}{l}\text { 13. Increasing the intensity of assigning assignments } \\
\text { to students to be motivated to search for } \\
\text { literature in the library }\end{array}$ & 18. Percentage of visitors in the library \\
\hline & $\begin{array}{l}\text { 14. Adding complete references and guidebooks in the } \\
\text { library }\end{array}$ & 19. Total literature in the library \\
\hline \multirow[t]{2}{*}{9} & 15. Improve school managerial duties and functions & $\begin{array}{l}\text { 20. Percentage of total school evaluation } \\
\text { meetings that are by the schedule }\end{array}$ \\
\hline & & $\begin{array}{l}\text { 21. Percentage of the total program of } \\
\text { socialization of the organization's vision, } \\
\text { mission, and strategy }\end{array}$ \\
\hline 10 & 16. Increase in the number of students in college & 22. Percentage of students in College \\
\hline \multirow[t]{3}{*}{11} & 17. Providing incentives for employees & 23. Percentage of employees who get incentives \\
\hline & 18. Provision of timely salaries & 24. Percentage of time to pay on time \\
\hline & $\begin{array}{l}\text { 19. Provision of decree teaching for teachers in the } \\
\text { field of study }\end{array}$ & $\begin{array}{l}\text { 25. The ratio of teaching to the total academic } \\
\text { staff }\end{array}$ \\
\hline 12 & $\begin{array}{l}\text { 20. Provision of teaching and learning tools before } \\
\text { teaching begins }\end{array}$ & $\begin{array}{l}\text { 26. Percentage of total teaching and learning } \\
\text { tools with total classrooms }\end{array}$ \\
\hline \multirow[t]{3}{*}{13} & 21. Increasing public interest to send their sons and & 27. Total registrants \\
\hline & daughters to school & 28. Percentage of total Drop Out students \\
\hline & & 29. Percentage of Total Graduates \\
\hline \multirow[t]{2}{*}{14} & $\begin{array}{l}\text { 22. Involving employees in the supervisory exam } \\
\text { committee }\end{array}$ & $\begin{array}{l}\text { 30. The ratio of employees involved in the } \\
\text { examination supervisory committee }\end{array}$ \\
\hline & 23. Provide a job description for each position & $\begin{array}{l}\text { 31. The ratio of job descriptions with total } \\
\text { positions }\end{array}$ \\
\hline \multirow[t]{2}{*}{15} & 24. Require teachers to make UOL & 32. UOL Ratio with Total subjects \\
\hline & 25. Monitor the suitability of teaching with UOL & $\begin{array}{l}\text { 33. The ratio of teaching conformity with UOL / } \\
\text { semester }\end{array}$ \\
\hline
\end{tabular}




\section{Result and Discussions}

This section describes the hierarchy of KPIs, weighting with AHP, and measurement of school performance with OMAX.

\subsection{The hierarchy of school performance}

Based on the results of the study, there are eight objectives of school performance. These include Human Resources (HR), Financial (Fi), Curriculum (Cur), Work programs (WP), Academic Administration (AA), Teaching and learning activities (TLA), Evaluation Process (EV), and Career Advance Studies (CAS) ) or Graduates. Fig. 4 describes The hierarchy of school performance. There are 33 KPIs assessed. HR had 7 KPI, Fi had 4 KPI, Cur had 2 KPI, WP had 2 KPI, AA had 4 KPI, TLA had 6 KPI, EV had 4 KPI, and CAS had 4 KPI.

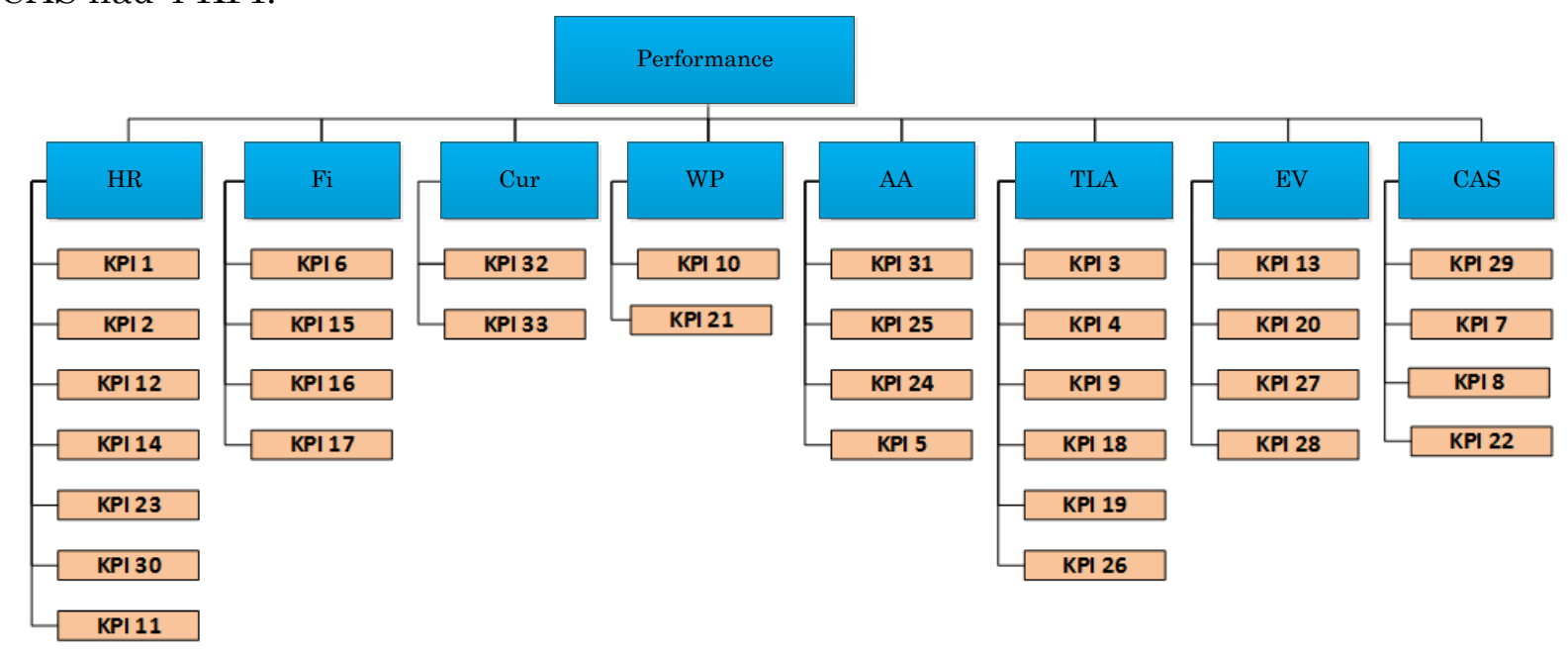

Fig. 4. The KPI Hierarchy of School Performance

\subsection{Weighting of Objectives and KPI}

Weighting KPI used the Analytical Hierarchy Process (AHP) with Expert Choice software. Table 3 describes the results of overall weighting performance.

Table 3. Results of wight overall performance

\begin{tabular}{lc}
\hline \multicolumn{1}{c}{ Objectives Group } & Weight (\%) \\
\hline Human Resources (HR) & 16.80 \\
Financial (Fi) & 20.20 \\
Curriculum (Cur) & 9.60 \\
Work program (WP) & 10.20 \\
Academic Administration (AA) & 5.00 \\
Teaching and learning activities (TLA) & 11.00 \\
Evaluation Process (EV) & 9.10 \\
Career Advance Studies (CAS) or Graduetes & 18.10 \\
Total & 100.00 \\
\hline Inconsistency ratio & $0.09 /$ Consistent \\
\hline
\end{tabular}

The highest weighting results were found in the financial aspects (Table 3). It shows that finance has a level of importance that determines school performance [15]. Private schools require fees for school operations. Therefore, finance is the most critical aspect [16]. It proved the research conducted by Franco-Santos [17]. The inconsistency 
ratio for overall performance is below 0.1. It shows results overall performance is consistent. Table 4 shows the weighting of each KPI Human Resources Performance. The highest weighting in Human Resources Performance was the average percentage of academic staff attendance. It increases Human Resources Performance and business performance [18]. Table 5 shows Weighting KPI Financial Performance. The percentage of achievement of the acceptance target was a priority for Financial Performance. Financial performance is a critical aspect of business performance [19]. The private school required Financial Performance from Tuition. Table 6 describes the weight KPI Curriculum Performance. The suitability ratio of teaching with UOL had a higher level of importance.

Table 7 shows the results of KPI Work Program Performance. The percentage indicator of the number of vision and mission socialization programs on schedule has a higher level of importance. Table 8 describes the Weighting results of KPI Administrative Performance. The number of academic staff is higher than other indicators that influence school performance. Table 9 shows the Weighting results of KPI Teaching and Learning Activities. The highest weighting results in the percentage indicator attendance. Table 10 describes the Weighting results of the KPI Performance Evaluation. The average value of supervision of study class teacher visits had a higher indicator. The school management has a high level of importance towards the indicators of supervision values. Table 11 describes the Weighting results of KPI Graduates Performance. The highest achievement of the NE value had significant indicators.

Table 4. Weight of KPI on Human Resources Performance

HR Performance KPI Group Weight (\%)

\begin{tabular}{lr}
\hline The average percentage of academic staff attendance & 27.10 \\
The ratio of permanent teachers to non-permanent teachers & 5.60 \\
The Ratio of academic staff attending training & 16.30 \\
Percentage of total academic staff with values below 6 & 6.30 \\
Percentage of employees who get incentives & 7.80 \\
The ratio of employees involved in the examination supervisory & 14.30 \\
The ratio of attendance of meeting participants & 22.60 \\
Total & 100.00 \\
Inconsistency ratio & 0.05 Consistent
\end{tabular}

Table 5. Weight of KPI Financial Performance

\begin{tabular}{lr}
\hline \multicolumn{1}{c}{ Financial Performance KPI Group } & Weight (\%) \\
The ratio of expenses to receipts & 16.20 \\
Percentage of achievement of acceptance target (Tuition) & 48.70 \\
Percentage of receipt of alms funds & 22.30 \\
Percentage of arrears & 12.80 \\
Total & 100.00 \\
\hline Inconsistency ratio & $0.06 /$ Consistent \\
\hline
\end{tabular}

Table 6. Weight of KPI Curriculum Performance KPI group curriculum performance Weight (\%)

The UOL ratio with total subjects $\quad 25.00$

$\begin{array}{lr}\text { The ratio of teaching conformity with UOL } & 75.00\end{array}$

$\begin{array}{lr}\text { Total } & 100.00\end{array}$

Inconsistency ratio $\quad 0.0 /$ Consistent 
Table 7. Weight of KPI Work Program Performance KPI Group Work program performance Weight (\%)

Meeting ratio according to schedule

Percentage of total vision mission socialization on schedule

75.00

Total 100.00

Inconsistency ratio $0.0 /$ Consistent

Table 8. Weight of KPI Administrative Performance KPI Administrative Performance Group Weight (\%)

Job description ratio with total position 12.70

Ratio with total academic staff 48.70

$\%$ timely salary

$\%$ timely delivery of reports

22.40

Total 100.00

Inconsistency ratio 0.06/ Consistent

Table 9. Weight of KPI Teaching and Learning Activities KBK Performance KPI Group Weight (\%)

$\%$ Total of Free Tiem 22.30

$\%$ of student attendance

The average score of English subjects

$\%$ of library visitors

Total library literature

$\%$ TLA tools with total classrooms

Total 100.00

Inconsistency ratio $0.08 /$ Consistent

Table 10. Weight results of KPI Performance Evaluation KPI Evaluation Performance Group

The average value of supervision of study class teacher visits Weight (\%)

$\%$ Total school evaluation meetings as scheduled

Total of Registrant

$\%$ Total of DO Student

Total

Inconsistency ratio

Table 11. Weight of KPI Graduates Performance

\begin{tabular}{lr}
\hline \multicolumn{1}{c}{ KPI Group Graduates Performance } & Weight (\%) \\
\hline \% Total Graduates & 4.40 \\
The average score of the NE score & 23.60 \\
Achievement of the highest score target of NE & 41.70 \\
\% Student enter College & 30.30 \\
Total & 100.00 \\
\hline Inconsistency ratio & $0.06 /$ Consistent \\
\hline
\end{tabular}

\subsection{Analyzing of Organizational Performance}

Fig. 5 shows the hierarchical structure results in school performance. The overall performance of a school is in yellow categories. It shows that school performance needs improvement. There are 2 include red categories. There are Financial (Fi), Teaching, and learning activities (TLA). Career Advance Studies (CAS) ) or Graduates include in yellow categories. There are 5 in the green category. These are Curriculum (Cur), Work programs (WP), Academic Administration (AA), Human Resources (HR), and Evaluation Process (EV). Financial is an essential aspect of school. Therefore, school performance is affected by financial performance. It proved research by Wijaya [20]. 


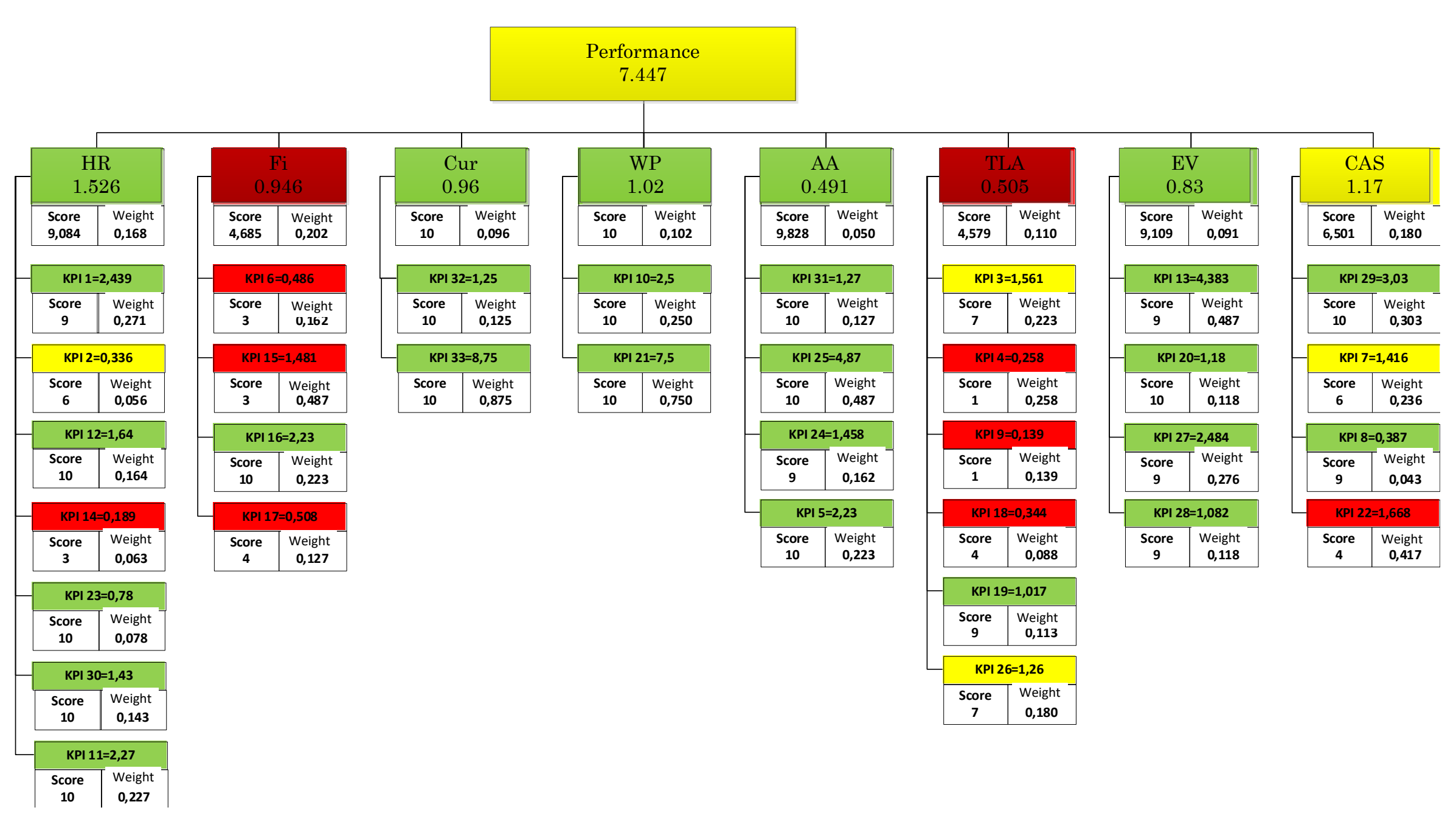

Fig. 5. The hierarchical structure results of school performance

doi)

Please cite this article as: Aziza, N., Suwignyo, P., \& Makki, A. (2019). Performance Measurement using the Integrated doi:https://doi.org/10.22219/JTIUMM.Vol20.No1.73-84 


\section{Conclusion}

Based on the study results, the school's performance is quite good because the performance indicator is yellow. From the results of weighting, the highest level of importance is financial. It shows that financial factors are still the dominant factor. Hence, schools can remain private schools. However, there are still several red KPIs that need improvement to improve school performance in the future. This performance measurement design can be a raw model of performance measurement design for other schools. However, for further research, this performance measurement design can be done using the balanced scorecard method. This method can be used because of the financial aspect as an essential aspect of improving performance.

\section{References}

[1] R. Simons, "How risky is your company?," Harvard business review, vol. 77, pp. 85-95, 1999.

[2] A. Neely, M. Gregory, and K. Platts, "Performance measurement system design: a literature review and research agenda," International journal of operations \& production management, vol. 15, pp. 80-116, 1995. https://doi.org/10.1108/01443579510083622.

[3] U. S. Bititci, P. Suwignjo, and A. Carrie, "Strategy management through quantitative modelling of performance measurement systems," International Journal of production economics, vol. 69, pp. 15-22, 2001. https://doi.org/10.1016/S0925-5273(99)00113-9.

[4] U. S. Bititci, A. S. Carrie, and L. McDevitt, "Integrated performance measurement systems: a development guide," International journal of operations \& production management, vol. 17, pp. 522-534, 1997. https://doi.org/10.1108/01443579710167230.

[5] B. Syairuddin, P. Suwignjo, and I. M. Suartika, "Perancangan dan implementasi sistem pengukuran kinerja dengan metode integrated performance measurement systems (studi kasus: jurusan teknik mesin Universitas Mataram)," Jurnal $\begin{array}{llllll}\text { Teknik Industri, } & \text { vol. } & \text { 9, } & \text { pp. } & \text { 131-143, } & \end{array}$ https://doi.org/10.9744/jti.9.2.pp.\%20131-143.

[6] J. Susetyo, "Penerapan Sistem Pengukuran Kinerja Perusahaan dengan Metode Integrated Performance Measurement Systems (IPMS) pada PT X," jurnal Teknologi, vol. 6, 2013.

[7] S. Widiyawati, S. Soeparman, and R. Soenoko, "Pengukuran Kinerja Pada Perusahaan Furniture Dengan Menggunakan Metode Performance Prism Dan Analytical Hierarchy Process," Journal of Engineering and Management in Industrial System, vol. 1, 2013. https://doi.org/10.21776/ub.jemis.2013.001.01.6.

[8] F. R. Maulidia, N. W. Setyanto, and A. Rahman, "Perancangan Sistem Pengukuran Kinerja Dengan Metode Integrated Performance Measurement System (IPMS)(Studi Kasus: KPRI Universitas Brawijaya)," Jurnal Rekayasa dan Manajemen Sistem Industri, vol. 2, pp. p1-10, 2014. http://jrmsi.studentjournal.ub.ac.id/index.php/jrmsi/article/view/55.

[9] E. Mas'idah, N. Khoiriyah, and T. Samudra, "Pengukuran kinerja perusahaan dengan metode integrated performance measurement system (IPMS) dan objective matrix (OMAX)(Studi kasus: PT. Nadira prima)," Prosiding SNST Fakultas Teknik, vol. 1, $2018 . \quad$ https://www.publikasiilmiah. unwahas.ac.id/index.php/PROSIDING_SNST_FT/article/view/2318. 
[10] F. H. Rachman and B. D. Satoto, "Sistem Pengukuran Kinerja Prodi Dengan Metode Integrated Performance Measurement Systems (Ipms) Dan MultiAttribute Utility Theory (MAUT)(Studi Kasus: Prodi Teknik Informatika UTM)," Rekayasa, vol. 5, pp. 123-132, 2012.

[11] I. Kurniyati, R. Zeline, and S. Y. Simanjuntak, "Perancangan Sistem Pengukuran Kerja dengan Metode Intergrated Performance Measurement System (IPMS)(Studi Kasus: CV. Ekasari)," PERFORMA: Media Ilmiah Teknik Industri, vol. 15, 2016. DOI: http://dx.doi.org/10.20961/performa.15.2.9858.

[12] J. Susetyo and A. Sabakula, "Pengukuran Kinerja Dengan Menggunakan Balanced Scorecard dan Integrated Performance Measurement System (IPMS)," $\begin{array}{llllll}\text { Jurnal Teknologi, vol. } & \text { 7, } & \text { pp. } & \text { 56-63, }\end{array}$ http://jurtek.akprind.ac.id/sites/default/files/56-63-susetyo.pdf.

[13] C. Kurniawan, A. Mubin, and H. M. Kholik, "Perancangan Integrated Environmental Performance Measurement System Di Rumah Sakit," Jurnal $\begin{array}{llllll}\text { Teknik Industri, } & \text { vol. } & \text { 18, } & \text { pp. } & 917,\end{array}$ https://doi.org/10.22219/JTIUMM.Vol18.No1.9-18.

[14] P. Papilo, "Integrasi Metode IPMS dan SMART System Dalam Pengukuran Kinerja Perguruan Tingi," Jurnal Teknik Industri, vol. 13, pp. 186-193, 2012. https://doi.org/10.22219/JTIUMM.Vol13.No2.186-193.

[15] D. A. Utama and R. Setiyani, "Pengaruh Transparansi, Akuntabilitas, Dan Responsibilitas Pengelolaan Keuangan Sekolah Terhadap Kinerja Guru,"

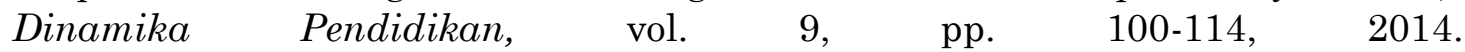
https://doi.org/10.15294/dp.v9i2.4886.

[16] L. J. Cronbach, R. L. Linn, R. L. Brennan, and E. H. Haertel, "Generalizability Analysis for Performance Assessments of Student Achievement or School Effectiveness," Educational and Psychological Measurement, vol. 57, pp. 373-399, 1997. https://doi.org/10.1177/0013164497057003001.

[17] M. Franco-Santos, "Towards a definition of a business performance measurement system," International Journal of Operations \&amp; Production Management, vol. 27, pp. 784-801, 2007. https://doi.org/10.1108/01443570710763778.

[18] A. K. Yeung and B. Berman, "Adding value through human resources: Reorienting human resource measurement to drive business performance," Human Resource Management, vol. 36, pp. 321-335, 1997. https://doi.org/10.1002/(SICI)1099-050X(199723)36:3<321::AID-HRM4>3.0.CO;2Y.

[19] J. Peloza, "Using Corporate Social Responsibility as Insurance for Financial Performance," California Management Review, vol. 48, pp. 52-72, 2006. https://doi.org/10.2307/41166338.

[20] D. Wijaya, "Model Balanced Scorecard dalam Implementasi Manajemen Berbasis Sekolah (MBS)," Ilmiah Manajemen Bisnis, vol. 14, pp. 45-58, 2014. http://ejournal.ukrida.ac.id/ojs/index.php/IMB/article/view/866. 